\title{
Knowledge and Attitude of Junior High School Students Towards Hydrometeorological Disaster Preparedness: A Case Study in Cirebon City, Province of West Java
}

\author{
Mega Indah Puspita Sari ${ }^{1, *}$ Mohammad Abdul Khafid ${ }^{2}$ Jumadi $^{3}$ \\ ${ }^{1}$ Master of Natural Science Education, Faculty of Mathematics and Natural Sciences, Universitas Negeri \\ Yogyakarta, Indonesia \\ ${ }^{2}$ Department of Environmental Engineering, Faculty of Mineral Technology, Universitas Pembangunan \\ Nasional Veteran Yogyakarta, Sleman, Indonesia \\ ${ }^{3}$ Department of Natural Science Education, Faculty of Mathematics and Natural Sciences, Universitas Negeri \\ Yogyakarta, Indonesia \\ *Corresponding author. Email: mega65pasca.2020@student.uny.ac.id
}

\begin{abstract}
Indonesia is a country of geological conditions located on three active tectonic plates that are almost entirely vulnerable to natural disasters. One of the cities with a high risk of disaster is Cirebon city. An individual's ability to cope with disasters is directly proportional to the level of preparedness in disaster risk. The purpose of the research is to analyse the knowledge and attitudes towards hydrometeorological disasters preparedness student of junior high school in Cirebon city. The method used in this study is a case study with a qualitative research approach from the study of 80 samples of students and structured interviews with descriptive analysis in Cirebon. The results showed that disasters can be influenced by natural and human factors, the ability to see disaster phenomena and countermeasures in every type of disaster around is good enough, internet media exerts a great influence on the source of disaster information, students knowledge of preparedness in the event of a disaster is almost entirely able to understand and analyze the potential disasters they will face. Education on disaster response should have started from the nearest neighborhood, namely families with government support through coordination with the relevant agencies.
\end{abstract}

Keywords: Hydrometerological disaster, Knowledge, Attitude, Junior high school

\section{INTRODUCTION}

Indonesia is one of the countries that geologically has a meeting of three active tectonic plates so that the region is prone to natural disasters. According to (Indonesian Law No. 24 of 2007) states that disaster is a series of events that can disrupt and threaten the life and economy of the community that can be caused by non-natural and natural factors resulting in loss of life, environmental degradation, property damage and public facilities and psychological disorders after the disaster [1]. While hydrometeorological disasters are disasters caused by extreme climate [2]. In general, about $98 \%$ of the total natural disaster events per year are hydrometeorological disasters such as drought, landslides, floods, forest and land fires, and ocean waves. The history of its development from 2010 to 2014 has occurred more than 1900 times with an average annual occurrence of 1124 times with the dominating disasters namely floods and landslides of 3032 times the death toll of 2326 people. The disaster that dominated was a landslide with a total of 3032 incidents that caused a death toll of 2326 people [3]. In general, disasters can be categorized based on the natural hazards that cause disasters. The classified based on the cause of occurrence, the environment of scene and the speed at which the disaster occurred [4]. Disasters are grouped into two namely natural disasters and artificial disasters. Natural disasters include several events such as landslides, volcanic 
eruptions, earthquakes, droughts, floods, storms, erosion, and tsunamis, while artificial disasters by human activities namely fires, nuclear radiation, oil spills, sewage pollution, pollution of air or rivers, destruction of water dams, biological disasters and traffic accidents [5]. Phenomenon every year natural and non-natural disasters have taken an average of 74000 lives and impacted approximately 230 million people worldwide. Disasters caused by human negligence usually have no causal relationship whatsoever with nature, and they are purely due to human activity [6]. Other impacts of disasters other than death and health are economic displacement and large-scale urbanization, injuries and economic losses for people. Therefore there is always the need to develop disaster response thinking through the collaboration of disciplines to reduce the risk of harm that can be inflicted [7].

Cirebon is the urban areas of Province in West Java with very rapid development, and is a core area or buffer area in Ciayumajakuning area which becomes the center of economy, industry and education center [8]. The risk of natural disasters is also high, influenced by geological conditions, geomorphology, meteorology and urbanization factors. Cirebon is an area that passes through the earthquake zone with high rainfall conditions during the rainy season in certain areas with steep topography conditions that can pose a risk of natural disasters such as floods, or landslides [9]. Highly dynamic human activity in urban areas combined with the meteorological conditions of beetle winds during the dry season period further makes the potential for heat and drought very high [10].

An individual's ability to cope with unexpected events, such as disasters, is determined by their level of preparedness, knowledge, and actions in the event of a disaster [11]. In this case methods to determine students' level of knowledge about disasters and disaster preparedness can contribute to disaster management. The purpose of this research is to knowledge and attitudes of hydrometeorological

\section{RESULT AND DISCUSSION}

Interviewed by students about how they define natural disasters, students are asked "What do natural disasters mean to you?". This question is answered by students and analyzed see in Table 2 . The results showed that the disaster caused damage to infrastructure (f 48) and caused casualties and buildings (f 23). The response of students who declared the disaster as major damage and loss of life, disasters preparedness student of junior high school in Cirebon city. The specifics of education have been towards determining students' perceptions of disasters and preparing appropriate programs related to disasters and measuring the level of impact [12].

\section{METHODS}

Research conducted is by qualitative research method. Data collection techniques are performed with interviews. Interview techniques conducted using structured interviews. The interview is read to the student then the student answers the given question. The data obtained is then analyzed through a descriptive analysis method, in which each student interviewed is coded. Each student's response is coded $\mathrm{S} 1, \mathrm{~S} 2, \mathrm{~S} 3 \ldots$ then the data is analyzed. Interviews were conducted at 4 Junior High Schools with Interviews were conducted at 4 school in 4 district including Talun district, Babakan district, Dukuhpuntang district, Kejaksan district (SMPN 1 Talun, MTS Islamiyah Darussalam, SMP IT Tarbiyatul Banin, and SMP IT Nuurusshidiq) with 80 junior high school students in Cirebon. Interview forms for awareness of the student disaster phenomenon by interviews were developed by researchers and then given to science lesson teachers. The questions are aimed at knowing the residual understanding of disasters and to know students' understanding of what was done at the time of the disaster. The theme of the question asked can be seen in Table 1 [13].

Table 1. Table of content research

\begin{tabular}{|l|l|}
\hline Theme & Question (No) \\
\hline $\begin{array}{l}\text { Definition about Natural } \\
\text { Disasters }\end{array}$ & 1 and 2 \\
\hline $\begin{array}{l}\text { Natural Disasters That } \\
\text { Occur in the Vicinity }\end{array}$ & 3 \\
\hline Disaster-Related Measures & $4,5,6,7$ and 8 \\
\hline
\end{tabular}

"S26: A natural event that caused great impact to the human population, the number of people's homes and public facilities damaged by natural disasters, "S13: A very severe event that resulted in dead, loss of place, and injuries. The rest suggest that natural disasters cause unforeseen events and cause economic problems. 
Table 2. Students' response to the definition of disaster, impact on people and the environment

\begin{tabular}{|c|l|c|}
\hline \multirow{2}{*}{$\begin{array}{c}\text { Type of disasters } \\
\text { Natural } \\
\text { Disasters }\end{array}$} & \multicolumn{1}{|c|}{ Impact of disaster } & \multicolumn{1}{|c|}{ Frequency } \\
\cline { 2 - 3 } & Causing Infrastructure damage & 28 \\
\cline { 2 - 3 } & Inflicting fatalities and property damage & 2 \\
\cline { 2 - 3 } & Occurs spontaneously & 6 \\
\cline { 2 - 3 } & Causing economic problems & 23 \\
\hline
\end{tabular}

Facilities damaged by natural disasters, "S13: A very severe event that resulted in death, loss of place, and injuries. The rest suggest that natural disasters cause unforeseen events and cause economic problems. Interviewed to find out what kind of disaster students know, students respond to the question "What natural disasters do you know?". Students can name more than one known event. So it gets results in Table
3. The student's response to the type of natural disaster known most to students is earthquakes. A total of 72 students were aware of the earthquake, and the least known type of natural disaster by students was erosion and eruptions. Erosion and eruption disasters are at least responded to by students because the research study area lies far from volcanic activity and students' ignorance about erosion disasters.

Table 3. Type of natural disaster in Indonesia

\begin{tabular}{|l|l|l|}
\hline \multicolumn{1}{|c|}{ Theme } & \multicolumn{1}{|c|}{ Type of natural disaster } & Frequency \\
\hline \multirow{3}{*}{ Type of Natural Disaster } & Earthquake & 72 \\
\cline { 2 - 3 } & Flood & 68 \\
\cline { 2 - 3 } & Landslide & 59 \\
\cline { 2 - 3 } & Fire & 30 \\
\cline { 2 - 3 } & Tsunami & 33 \\
\cline { 2 - 3 } & Drought & 39 \\
\cline { 2 - 3 } & Storm & 28 \\
\cline { 2 - 3 } & Erosion & 31 \\
\cline { 2 - 3 } & Volcanic Activity (Eruptions) & 39 \\
\hline
\end{tabular}

To find out the level of knowledge of students about the types of natural disasters that occur around them, researchers ask the question "What natural disasters have occurred in Cirebon area?". The analysis of students' responses can be found in Table 4. The results of the analysis are known that the types of disasters encountered and most often occur around them are floods and fires. This is because Cirebon area is dominated by lowlands and the area is included in the northern coastal area which makes the area often flooded especially during the rainy season and wind Table 4. Students responses about disaster phenomenon in around

\begin{tabular}{|l|l|l|}
\hline \multicolumn{1}{|c|}{ Theme } & \multicolumn{1}{c|}{ Phenomenon } & Frequency \\
\hline Disaster events you've seen around the residence & Flood & 46 \\
\cline { 2 - 3 } & Fire & 47 \\
\cline { 2 - 3 } & Drought & 49 \\
\cline { 2 - 3 } & Landslide & 13 \\
\cline { 2 - 3 } & Storm & 13 \\
\hline
\end{tabular}

conditions and seawater waves rise to the surface of the land. Some students responded to the avalanche (f6), such as the response "S24: there was an avalanche when it rained" this was due to the area where the students lived in Dukupuntang sub-district of Cirebon district, where the area has a topographic tends to be steep lym as steep so that during the rainy season there is a very potential landslide. When the rainy season arrives, there are frequent landslides in the region more than once a year. 


\begin{tabular}{|c|c|c|}
\hline Theme & Phenomenon & Frequency \\
\hline \multirow[t]{5}{*}{ Disasters are most likely to occur in your residence } & Flood & 53 \\
\hline & Fire & 32 \\
\hline & Drought & 25 \\
\hline & Landslide & 6 \\
\hline & Storm & 5 \\
\hline \multirow[t]{5}{*}{ A vulnerable and potentially large disaster occurred in Cirebon } & Flood & 65 \\
\hline & Fire & 50 \\
\hline & Drought & 50 \\
\hline & Landslide & 23 \\
\hline & Storm & 22 \\
\hline
\end{tabular}

In the next stage of the interview, to find out the source of disaster information obtained by students is given the question "where do you know information about the disaster?". Student responses can be viewed in detail in Table 5. Based on Table 5, about the source of disaster information, the most frequency of information sources are derived from period media (f63). This is because access to information in the global era is very easy to obtain, starting from television and the internet. The habits of middle students who prefer audio visual media as a source of information. In addition to the media of the time, the school also has a large role in the spread of disaster information to students, usually students are informed from the school through wall magazines as well as the delivery of materials by teachers during the learning process. In this case, the school needs to provide students with an understanding through interactive ways for students to like or be interested in the disaster information submitted.

Table 5. Students' responses to the source of disaster information

\begin{tabular}{|l|c|}
\hline \multicolumn{1}{c|}{ Source of information } & \multicolumn{1}{c|}{ Frequency } \\
\hline School wall magazine & 50 \\
\hline Information media & 63 \\
\hline Family & 34 \\
\hline Around the residence & 43 \\
\hline
\end{tabular}

The analysis results of students' knowledge of disaster prevention measures show that in flood disasters students choose the most greening (f40). According to "S67: tree planting needs to be done to absorb puddles so that there is no flood". The most common fire prevention measure for students is not to throw cigarette butts indiscriminately (f67). Cirebon regency has geomorphological conditions, namely hills that have the potential for soil movement. The most important precautions answered by students are building buildings in flat or ramped areas (f39). The last natural disaster analyzed was an earthquake, although the point of the earthquake location was unprecedented in Cirebon, there is the potential for earthquakes in the region, so students need to know the prevention of earthquake disasters. The most preferred action of students is to build buildings with strong, durable materials (f57).

Table 6. Students' responses to disaster mitiagtions

\begin{tabular}{|c|l|c|}
\hline \multirow{2}{*}{ Type of disaster } & \multicolumn{1}{|c|}{ Prevention } & \multicolumn{1}{|c|}{ Frequency } \\
\hline \multirow{2}{*}{ Flood } & Reforestation & 40 \\
\cline { 2 - 3 } & Construction of dams & 36 \\
\cline { 2 - 3 } & vertical mulch (Biopori) & 21 \\
\cline { 2 - 3 } & waste dumps in place & 55 \\
\hline Fire & remove cigarette butts in place & 67 \\
\hline
\end{tabular}




\begin{tabular}{|c|l|l|}
\hline \multicolumn{1}{|c|}{ Type of disaster } & \multicolumn{1}{|c|}{ Prevention } & \multicolumn{1}{|c|}{ Frequency } \\
\hline \multirow{2}{*}{ Landslide } & air circulation is good & 30 \\
\cline { 2 - 3 } & fire extinguisher facilities available & 28 \\
\hline & Reforestation & 31 \\
\cline { 2 - 3 } & construction of retaining walls on slopes & 27 \\
\cline { 2 - 3 } & building on a flat area & 39 \\
\hline \multirow{2}{*}{ Earthquake } & use of strong and durable building materials & 57 \\
\cline { 2 - 3 } & building houses in areas safe from earthquakes & 52 \\
\hline
\end{tabular}

Interviewed to find out students' understanding of institution both from the government and private sector that plays a role in disaster management, the students were asked "What are the institutions that play a role in disaster management in Cirebon city? The results of the interview found that 31 students did not know and 20 answered more than two institutions. The results of the interview show that students are likely to call BPBD (Cirebon City) as the first option, while their last option will be to call the TAGANA team from social services. More info can be found in
Table 7. In an interview to find out the preparedness of disasters in the area around where they live, the question is asked about "What disaster mitigation facilities and what actions have the relevant parties taken to you?. The results in Table 7 show that 50 students answered not knowing and 30 students answered the most have been given training and simulation of natural disasters by TAGANA, while students' knowledge of the early warning system is still at least 6 students.

Table 7. Students' responses to institution role in disaster management

\begin{tabular}{|l|c|}
\hline \multicolumn{1}{|c|}{ Disaster management organization in Cirebon } & Frequency \\
\hline BPBD (Cirebon City) & 49 \\
\hline PMI & 21 \\
\hline TAGANA & 14 \\
\hline
\end{tabular}

In an interview to find out the preparedness of disasters in the area around where they live, the question is asked about "What disaster mitigation facilities and what actions have the relevant parties taken to you?. The results in Table 8 showed that 50 students answered not knowing and 30 of the most answered students had been given training and natural disaster simulation by TAGANA (Taruna Tanggap Bencana), while students' knowledge of the early warning system was still at least 6 students.

Table 8. Students' responses to disaster preparedness

\begin{tabular}{|l|c|}
\hline Disaster preparedness & Frequency \\
\hline $\begin{array}{l}\text { There are evacuation routes and disaster information boards in schools and } \\
\text { public facilities. }\end{array}$ & \\
\hline Disaster response training and simulation & 30 \\
\hline Early Warning System & 8 \\
\hline
\end{tabular}

In interviews of students' perceptions of actions taken in the event of a disaster, the students were asked "What does a sudden disaster do?. Results showed (see Table 9), the dominant students responded calmly and searched for safe evacuation routes, while 12 students responded with fear and silence. Based on the results of the student response analysis in Table 9, it is known that most students know what to do at the time of the disaster. Nevertheless, disaster response socialization needs to be done both in school and in the home 
environment. Usually, natural disasters that can occur at any time so there needs to be preparedness.

Table 9. Students' responses to attitude of a disaster

\begin{tabular}{|l|l|}
\hline \multicolumn{1}{|c|}{ Student attitude in the event of a disaster } & Frequency \\
\hline Fear and silence & 12 \\
\hline panic and undirected running & 36 \\
\hline feel safe and not take any action & 14 \\
\hline calm down and seek evacuation routes & 55 \\
\hline
\end{tabular}

In general, the results of this study are used to express students' awareness of disasters, which is seen that students regard the phenomenon of disaster that causes damage and inflicts material and soul loss. But some students still use the definition of disaster as an event influenced by natural factors only, the existence of human factors is rarely expressed. This should be a concern in the design of curriculum and textbooks about natural disaster factors human components need to be included in research and literature studies [8] [17]. Students' perception of natural disaster management is good enough but there are still students who do not know the specifics of the disaster [14\}. The most resources about disasters obtained by students, namely digital information media or google can be learning for the school to provide a lot of disaster information through learning and textbooks. Students' knowledge of disaster management institutions is good enough that more than $50 \%$ of students already know where to report. But disaster preparedness, especially from physical facilities and coaching or disaster training is still quite minimal only around 35\% only [15] [16]. Relevant agencies such as BPBD and TAGANA Cirebon city should work with schools to conduct disaster training at least once every semester on students. Evacuation routes, early warning systems and disaster information should be more installed in places with potential disasters. Students' actions in the event of a disaster based on their response are already $50 \%$ they understand what they have to do in the event of a disaster, but this can not be a reference because it must be done testing through disaster simulation first. Based on this, the level of preparedness and awareness of disasters among junior high school students in Cirebon is good enough, but it needs to be improved again to simulate disaster response training, information media and supporting fisk facilities in the area around disaster-prone.

\section{CONCLUSION}

Based on analysis can be concluded that the attitude and knowledge of junior high school in Cirebon is good enough, but still needs to be improved in terms of disaster response training simulation for teachers and students who have to be in the school curriculum. In addition, families also have a very important role to convey information to their children about disasters and their repatriation and give the responsibility of family to know the actions taken in the moments before the disaster, the disaster, and after the disaster occurred.

\section{ACKNOWLEDGMENTS}

This research was supported by Department of Science Education, Graduate School of Yogyakarta State University and Environmental Engineering, Faculty of Mineral Technology, Universitas Pembangunan Nasional Veteran Yogyakarta.

\section{REFERENCES}

[1] Ministry of Education and Culture, Regulation of The Minister of Education and Culture No. 24 of 2007 for Disaster Mitigation, Jakarta, 2007.

[2] H. Wu, M. Huang, Q. Tang, D.B. Kirschbaum, P. Ward, Hydrometeorological Hazards: Monitoring, Forecasting, Risk Assesment, and Socioeconomic Responses, Advances in Meteorology, (2016) (2016) 1-3. DOI: http://dx.doi.org/10.1155/2016/2367939

[3] S.C. Chung, C.J. Yen, Disaster Prevention Literacy among School Administrators and Teachers: A Study on The Plan for Disaster Prevention and Campus Network Deployment and Experiment in Taiwan, Journal of Life Sciences 10(4) (2016) 203-214. DOI: https://doi.org/10.17265/1934-7391/2016.04.006 
[4] G. Tuladhar, R. Yatabe, R.K. Dahal, N.P. Bhandary, Geomatics, Natural Hazards and Risk 5(3) (2014) 190-207. DOI: https://doi.org/10.1080/19475705.2013.809556

[5] K.R. Ronan, D.M. Johnston, BehaviourallyBased Interventions for Children Following Volcanic Eruptions An Evaluation of Effectiveness, Disaster Prevention and Management 8(3) (1999) 169-176. DOI: https://doi.org/10.1108/09653569910275364

[6] J.S. Ganpatrao, Knowledge and Practices of School Teacher Regarding Disaster Management, International Journal of Health System Disaster \& Management 2(2) (2014) 98102. DOI: https://doi.org/10.4103/2347$\underline{9019.139055}$

[7] C.J.L. Dibben, D.K. Chester, Human Vulnerability in Volcanic Environments: The Case of Furnas, Sao Miguel, Azores, Journal of Volcanology and Geothermal Research 92(1-2) (1999) 133-150.

DOI: https://doi.org/10.1016/S0377-0273(99)00072-4

[8] M.A. Khafid, Correlation analysis of the impact of land cover change and ratio vehicles on the dynamic of land surface temperature: case studies of Cirebon City, Province of West Java, in: IOP Conference Series: Earth and Environmental Science, vol. 399, IOP Publishing, Bristol, 2019, pp. 1-8. DOI: https://doi.org/10.1088/1755$\underline{1315 / 399 / 1 / 012096}$

[9] M.A. Widiawaty, M. Dede, Pemodelan Spasial Bahaya dan Kerentanan Bencana Banjir di Wilayah Timur Kabupaten Cirebon, Jurnal Dialog Penanggulangan Bencana 9(1) (2018) 142-153.

DOI: https://doi.org/10.31227/osf.io/kshb2
[10] M.A. Widiawaty, M. Dede, A. Ismail, Comparative Study Modeling of Ground Water Using Geographic Information System in Kayuambon Village, Bandung Barat Regency, Jurnal Geografi Gea 18(1) (2018) 63-71. DOI: https://doi.org/10.17509/gea.v18i1.10397

[11] E.B. Kirikkaya, O. Çakın., B. İmali, E. Bozkurt, Earthquake training is gaining importance: the views of 4th and 5th year students on earthquake, in: Procedia-Social and Behavioral Sciences, vol. 15, Istanbul. Turkey, 2011 pp. 2305-2313. DOI: https://doi.org/10.1016/j.sbspro.2011.04.098

[12] Indonesia Statistik, Central Bureau of Statistics, BPS-Statistics Indonesia, 2018.

[13] A. Pinar, What is secondary school students a awarness on disasters? A case study, in: Review of International Geographical Education Online Dergipark Akademik, vol. 1400, Turkey, 2017, pp. 315-331.

[14] B. Rohrmann, Community-Based Fire Preparadness Programmes: AN Empirical Evaluation, The Australasian Journal of Disaster and Truma Studies 1999(1) (1999) 1-13.

[15] M.D. Gall, W.R. Borg, J.P. Gall, Educational Research An Introduction, Longman Publishing, 1996.

[16] McMillian, H. James, Educational Research: Fundemental for The Consumer Second Edition, HarperCollins College Publisher, 1996.

[17] G. Rajesh, K.G. Chhabra, P.J. Shetty, K.V.V Prasad, S.B. Javali, A Survey on Disaster Management among Postgraduate Students in a Private Dental Institution in India, American Journal of Disaster Medicine (5) (2011) 309-318. DOI: https://doi.org/10.5055/ajdm.2011.0070 